Article

\title{
Examining Spatial Distribution and Dynamic Change of Urban Land Covers in the Brazilian Amazon Using Multitemporal Multisensor High Spatial Resolution Satellite Imagery
}

\author{
Yunyun Feng ${ }^{1,2}$, Dengsheng Lu ${ }^{1,2, *}$, Emilio F. Moran ${ }^{2}$, Luciano Vieira Dutra ${ }^{3}$, \\ Miquéias Freitas Calvi ${ }^{4}$ and Maria Antonia Falcão de Oliveira ${ }^{3}$ \\ 1 The Nurturing Station for the State Key Laboratory of Subtropical Silviculture, Key Laboratory of Carbon \\ Cycling in Forest Ecosystems and Carbon Sequestration of Zhejiang Province, School of Environmental \& \\ Resource Sciences, Zhejiang Agriculture and Forestry University, Lin An 311300, China; fengyyfm@163.com \\ 2 Center for Global Change and Earth Observations, Michigan State University, East Lansing, MI 48823, USA; \\ moranef@msu.edu \\ 3 National Institute for Space Research, Av. dos Astronautas, 1758, São Jose dos Campos, SP 12245-010, Brazil; \\ dutra@dpi.inpe.br (L.V.D.); marian.florestal@gmail.com (M.A.F.d.O.) \\ 4 Forestry Faculty, Federal University of Pará, Altamira, PA 68372-040, Brazil; mcalvi@ufpa.br \\ * Correspondence: luds@zafu.edu.cn; Tel./Fax: +86-571-6374-6366
}

Academic Editors: Weiqi Zhou, Junxiang Li, Conghe Song, Parth Sarathi Roy and Prasad S. Thenkabail Received: 5 February 2017; Accepted: 17 April 2017; Published: 19 April 2017

\begin{abstract}
The construction of the Belo Monte hydroelectric dam began in 2011, resulting in rapidly increased population from less than 80,000 persons before 2010 to more than 150,000 persons in 2012 in Altamira, Pará State, Brazil. This rapid urbanization has produced many problems in urban planning and management, as well as challenging environmental conditions, requiring monitoring of urban land-cover change at high temporal and spatial resolutions. However, the frequent cloud cover in the moist tropical region is a big problem, impeding the acquisition of cloud-free optical sensor data. Thanks to the availability of different kinds of high spatial resolution satellite images in recent decades, RapidEye imagery in 2011 and 2012, Pleiades imagery in 2013 and 2014, SPOT 6 imagery in 2015, and CBERS imagery in 2016 with spatial resolutions from $0.5 \mathrm{~m}$ to $10 \mathrm{~m}$ were collected for this research. Because of the difference in spectral and spatial resolutions among these satellite images, directly conducting urban land-cover change using conventional change detection techniques, such as image differencing and principal component analysis, was not feasible. Therefore, a hybrid approach was proposed based on integration of spectral and spatial features to classify the high spatial resolution satellite images into six land-cover classes: impervious surface area (ISA), bare soil, building demolition, water, pasture, and forest/plantation. A post-classification comparison approach was then used to detect urban land-cover change annually for the periods between 2011 and 2016. The focus was on the analysis of ISA expansion, the dynamic change between pasture and bare soil, and the changes in forest/plantation. This study indicates that the hybrid approach can effectively extract six land-cover types with overall accuracy of over $90 \%$. ISA increased continuously through conversion from pasture and bare soil. The Belo Monte dam construction resulted in building demolition in 2015 in low-lying areas along the rivers and an increase in water bodies in 2016. Because of the dam construction, forest/plantation and pasture decreased much faster, while ISA and water increased much faster in 2011-2016 than they had between 1991 and 2011. About $50 \%$ of the increased annual deforestation area can be attributed to the dam construction between 2011 and 2016. The spatial patterns of annual urban land-cover distribution and rates of dynamic change provided important data sources for making better decisions for urban management and planning in this city and others experiencing such explosive demographic change.
\end{abstract}


Keywords: urban land-cover change; high spatial resolution satellite images; multisensor data; change detection technique; moist tropical region; Belo Monte hydroelectric dam construction

\section{Introduction}

The construction of the Belo Monte hydroelectric dam near Altamira, Pará State, Brazil, has attracted a large population to this region, resulting in unprecedented land-cover change in the past five years (2011-2016). The rapid increase in population in a short period due to migration from other locations and relocation from areas being flooded by the new reservoir and rising river requires a large number of houses in urban and rural areas of Altamira, producing many challenges in urban planning and management and resulting in environmental problems [1-3]. It is an urgent task to map urban land-cover distribution and its dynamic change at high temporal and spatial resolutions to provide scientific data for effectively planning and managing urban expansion and construction. This situation will be common in Brazilian moist tropical regions due to many planned dams along major rivers such as Xingu, Tapajos, and Madeira [1].

Remote sensing using optical sensor data has been regarded as the most effective data for land-cover classification; thus, a large number of applications and studies have been conducted at different scales [4-6]. However, in the moist tropical region, cloud cover is the major constraint for obtaining cloud-free optical sensor data [7], making it difficult to study land-cover change detection using that type of data [8,9]. In recent decades, the availability of many satellite images such as IKONOS, QuickBird, Worldview, Pleiades, RapidEye, and SPOT 6 with high spatial resolutions make it possible to examine land-cover change using different sensor data. However, this situation brings new challenges in conducting change detection analysis because the current techniques are mainly based on the same sensor data with a multitemporal scale $[9,10]$ to reduce the influences of different spatial and spectral resolutions on the change detection results.

Landsat has been the most common source of data for land-cover classification and change detection due to its long-term data availability at no cost $[5,6,11]$, but its $30 \mathrm{~m}$ spatial resolution has been regarded too coarse for urban land-cover studies because of the complex composition of different land-cover types with small patch sizes [12,13]. Therefore, high spatial resolution imagery (better than $5 \mathrm{~m}$ ) is necessary for accurate urban land-cover classification and has been extensively used in recent decades [14,15]. Compared to Landsat imagery with $30 \mathrm{~m}$ spatial resolution, high spatial resolution satellite imagery has its merits and shortcomings. For example, rich spatial information with clear shapes of different land covers is very suitable for visual interpretation [14], but produces high spectral variation for the same land cover such as building roofs, roads/streets and parking lots, and shadows from tall objects (e.g., tree crowns and buildings), resulting in difficulty in automatic land-cover classification [15]. Also, most high spatial resolution images only include visible and near-infrared (NIR) bands without shortwave infrared wavelengths, resulting in difficulty in classification of some land covers such as different forest types [4].

Selection of suitable remote sensing variables and corresponding classification algorithms is critical for accurate land-cover classification [4,9]. Many previous studies have indicated that pure spectral features in high spatial resolution images such as QuickBird cannot provide accurate land-cover classification using computer-based automatic classification approaches [14,15], but the incorporation of spatial information such as textural images into spectral bands or use of segmentation-based variables considerably improved the classification [15-17]. Also, pixel-based classification approaches such as maximum likelihood classifiers are not as good as object-based classification approaches for high spatial resolution images [15,18-21]. Some machine-learning approaches such as support vector machine (SVM) and neural network that can handle high-dimensional data without assumption of normal data distribution have been proven to provide better classification performance than conventional statistical-based approaches [22,23]. Qian et al. [24] compared SVM, normal Bayes (NB), classification 
and regression tree (CART), and $\mathrm{K}$ nearest neighbor $(\mathrm{KNN})$, and found that SVM and NB had better performance than CART and KNN for high spatial resolution images.

The repeated acquisition of satellite imagery make it ideal for examining land-cover change, thus many studies explored the approaches to conduct land-cover change detection at different scales [9,25-28]. Although Landsat imagery is often used at local and regional scales $[6,8,11,29,30]$, its $30 \mathrm{~m}$ spatial resolution cannot effectively represent the spatial patterns of complex land-cover composition in urban landscapes. Therefore, high spatial resolution imagery (e.g., finer than $5 \mathrm{~m}$ ) is needed but has not been extensively used for land-cover change detection [9]. The major reasons may be (1) the cost of image purchase, (2) the relatively short-term data availability, (3) the wide spectral variation of the same land-cover types, (4) the different displacements due to various sun elevation angles and sun azimuth angles between multiple image acquisition dates [14], and (5) different shapes and sizes of shadows caused by tall objects (e.g., buildings, tree crowns) due to various sun elevation angles [14].

In the last decade, the availability of different sensor data with high spatial resolutions provides a new opportunity for urban land-cover change detection. This is especially valuable in moist tropical regions where frequent cloud covers restrain the collection of the same optical sensor data $[7,8]$. However, the difference in spectral, spatial, and radiometric resolutions in different sensor data produces new challenges for conducting land-cover change analysis because current change detection techniques are mainly developed based on the same sensor data. The changed areas in the urban landscape are often scattered in different locations with small patch sizes, requiring use of high spatial resolution imagery to detect the change. For example, Altamira has experienced a rapid urban expansion due to rapid population migration caused by nearby dam construction. Because the sizes of houses and apartments are usually much smaller than the cell size of Landsat imagery, we have to use high spatial resolution images. However, the frequent cloud cover restrains collection of the same sensor data; thus, we have to search whatever data with high spatial resolution are available for this study. This requires us to develop new approaches suitable for the specific sensor data for accurate land-cover classification and change detection.

The overall goal of this research is to develop a comprehensive approach to map land-cover distribution and its dynamic change in an urban landscape of the Brazilian Amazon using different sensor data with high spatial resolutions. Specifically, the objectives are to develop approaches suitable for different sensor data for accurately mapping urban land-cover distribution, and to examine annual urban land-cover dynamic change in a rapid urbanization region. The approach proposed in this research will be valuable for other studies where many planned dams will be built in the Amazon. This kind of high spatial and temporal land-cover distribution and dynamic change data will be valuable for conducting effective management of urban land use and environmental conditions in rapidly urbanizing regions.

\section{Study Area}

Altamira was selected to examine urban land-cover change (Figure 1). It is of relatively recent occupation in the region, coming from the National Integration Program of the military government that began in the early 1970s [31,32]. This region had a fast urban expansion starting in 2011 with the dam construction of the Belo Monte hydroelectric plant. The dam construction was almost finished in 2016, and water bodies (i.e., the reservoir and canals) increased considerably, as shown in Figure 1. According to Brazilian census data, the population in Altamira was 50,145 in 1991, 62,285 in 2000, and 77,195 in 2010 (IBGE: http:/ / www.ibge.gov.br/home/), but it jumped to approximately 150,000 in 2012 [33].

The Belo Monte dam, the third-largest hydroelectric in the world, with an 11.2 GW capacity, behind Three Gorges in China (18.2 GW) and Itaipu in the Paraná River between Brazil and Paraguay $(14 \mathrm{GW})$, is a major project. Investments linked to the Belo Monte dam, as well as several other private initiatives installed after construction began, allowed the city to experience rapid economic growth, expansion of commercial activities, expansion of jobs and miscellaneous services, and growth of the 
urban structure [34]. Recent changes in the landscape of Altamira are results of actions linked to Belo Monte dam or other actions presented as fundamental to the population, defined as responsibilities of the dam construction company as a condition for obtaining environmental and operating licenses.

As a security quota for the flooded area, houses and buildings located below $100 \mathrm{~m}$ in relation to average sea level were demolished, compulsorily displacing more than 16,000 people to six Collective Urban Resettlements [35] built exclusively for the displaced population. In addition to these settlements, six new private residential neighborhoods were built in the city, and established neighborhoods were expanded in cattle ranching areas, these being the main driving forces for land-use and land-cover change.
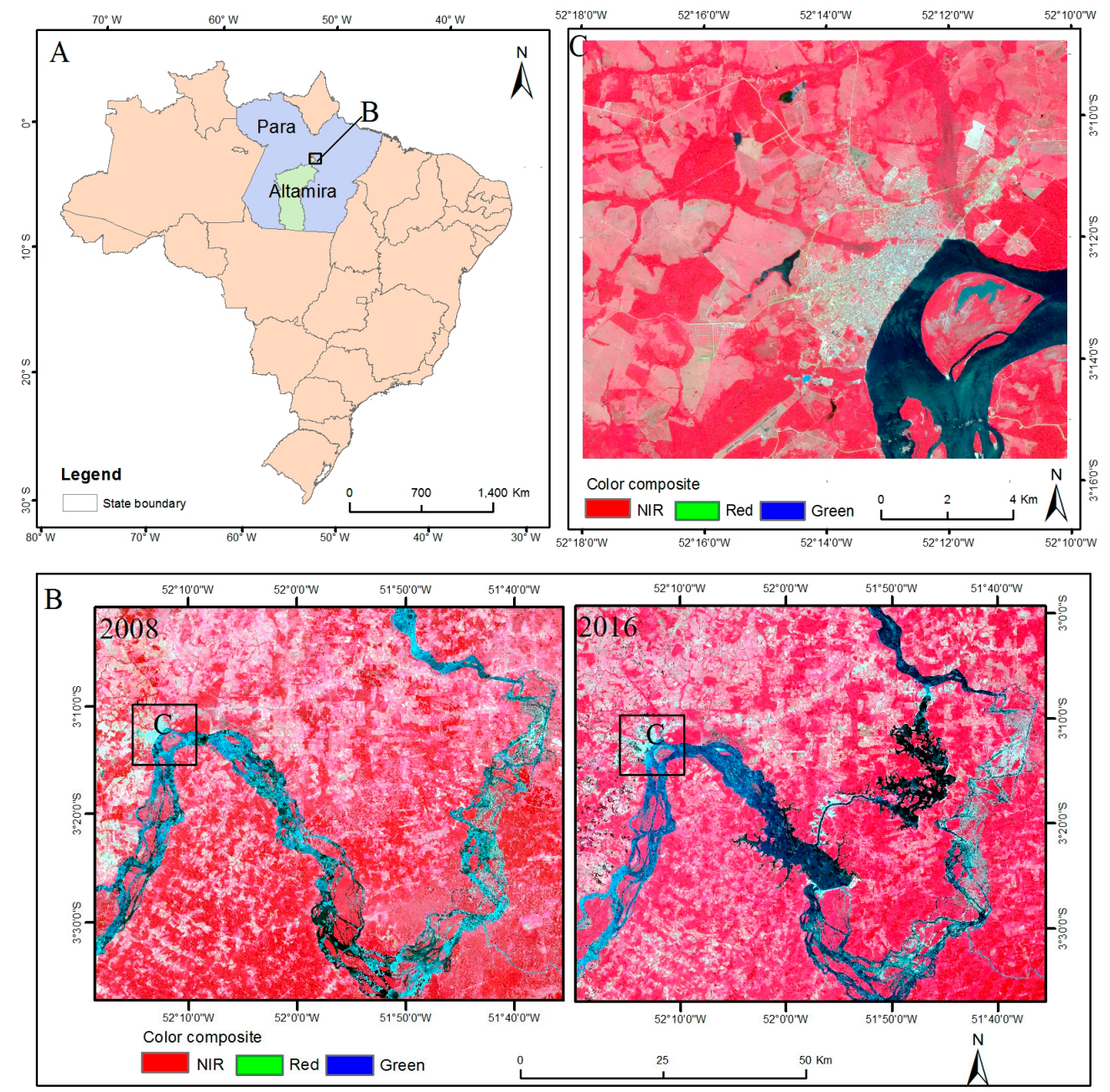

Figure 1. Study area and big change in water bodies before and after dam construction. (A) Location of Altamira within Brazil; (B) Landsat color composite using near-infrared (NIR), red, and green (30-m spatial resolution) as RGB for a comparison of water bodies in 2008 (Landsat TM) and 2016 (Landsat 8 OLI); (C) SPOT 6 color composite (1.5 m spatial resolution) in 2015 using NIR, red, and green as RGB.

\section{Materials and Methods}

\subsection{Data Collection and Preprocessing}

Table 1 summarizes the spectral and spatial features of the collected remote sensing data in this research, and the image acquisition dates. The satellite images were atmospherically calibrated using the dark-object subtraction approach [36,37]. No topographic correction was needed in this study because of the relatively flat terrain and lack of high spatial resolution digital elevation model 
(DEM) data. Because Pleiades, SPOT 6 and CBERS have multispectral and panchromatic data with various spatial resolutions, proper integration of them can improve spatial resolution while preserving spectral features. Many fusion techniques such as principal component analysis (PCA), intensity-hue-saturation (IHS), and wavelet are available, as previous literature has noted (e.g., [38,39]). Some fusion techniques such as IHS and PCA can effectively improve the spatial features that may be suitable for visual interpretation, but they may considerably distort spectral features critical for quantitative analysis [40,41]. Previous research on data fusion approaches based on Landsat and ALOS PLASAR L-band data indicated that preserving the fidelity of spectral features in addition to improving spatial resolution is critical for land-cover classification in the Amazon basin [40]. The exploration using different data fusion approaches (e.g., IHS, PCA) in this research found that the Gram-Schmidt Pan Sharpening approach provided better performance in preserving the spectral signatures, a conclusion similar to what other authors have obtained (e.g., [42,43]). Therefore, this data fusion approach was used in this research for the integration of multispectral and panchromatic data in the Pleiades, SPOT 6 and CBERS, as well as the fusion of different sensor data. The fused SPOT 6 imagery in 2015 was used as reference data; other images such as Pleiades, RapidEye, and CBERS were registered into the same coordinate system.

Table 1. Characteristics of optical sensor data used in this research.

\begin{tabular}{|c|c|c|c|c|}
\hline & RapidEye & Pleiades & SPOT 6 & CBERS \\
\hline \multirow{6}{*}{ Spectral bands } & & $480-830$ nm (Pan) & $450-745 \mathrm{~nm}$ (Pan) & \multirow{2}{*}{$510-850$ nm (Pan) } \\
\hline & $440-510$ nm (B) & $430-550 \mathrm{~nm}(\mathrm{~B})$ & $450-525 \mathrm{~nm}(\mathrm{~B})$ & \\
\hline & $520-590 \mathrm{~nm}(\mathrm{G})$ & $490-610 \mathrm{~nm}(\mathrm{G})$ & $530-590 \mathrm{~nm}(\mathrm{G})$ & $520-590 \mathrm{~nm}(\mathrm{G})$ \\
\hline & 630-685 nm (R) & $600-720 \mathrm{~nm}(\mathrm{R})$ & 625-695 nm (R) & $630-690 \mathrm{~nm}(\mathrm{R})$ \\
\hline & 690-730 nm (R Edge) & & & \\
\hline & $760-850 \mathrm{~nm}(\mathrm{NIR})$ & 750-950 nm(NIR) & 760-890 nm (NIR) & 770-890 nm (NIR) \\
\hline Spatial resolution & $\begin{array}{l}\text { Ground sampling } \\
\text { distance (nadir): } 6.5 \mathrm{~m} \\
\text { Pixel size: } 5 \mathrm{~m}\end{array}$ & $\begin{array}{l}\text { Pan: } 0.5 \mathrm{~m} \\
\text { MS (B, G, R, NIR): } 2.0 \mathrm{~m}\end{array}$ & $\begin{array}{l}\text { Pan: } 1.5 \mathrm{~m} \\
\text { MS (B, G, R, NIR): } 6.0 \mathrm{~m}\end{array}$ & $\begin{array}{l}\text { Pan: } 5 \mathrm{~m} \\
\text { MS (G, R, NIR): } 10 \mathrm{~m}\end{array}$ \\
\hline Image acquisition date & $\begin{array}{l}28 \text { July } 2011 \\
1 \text { August } 2012\end{array}$ & $\begin{array}{l}\text { 13 July } 2013 \\
18 \text { July } 2014\end{array}$ & 19 August 2015 & 3 July 2016 \\
\hline
\end{tabular}

Note: MS, Multispectral bands; Pan, Panchromatic band; B, G, R, NIR represent blue, green, red, and near-infrared wavelengths, respectively; SPOT, Système Pour 1'Observation de la Terre (French remote sensing satellite); CBERS, China-Brazil Earth Resources Satellite.

In this research, different sensor data have various spatial resolutions, but it is important to use the same cell size for each, so change detection can be effectively conducted. Because of the huge data volume in Pleiades images (0.5 m for the fused image) in 2013 and 2014, extraction of textures (especially when the window size is large, such as $15 \times 15$ pixels) and segmentation images becomes extremely time-consuming. Therefore, the fused Pleiades imagery with $0.5 \mathrm{~m}$ spatial resolution was resampled to a cell size of $1.5 \mathrm{~m}$, the same pixel size as SPOT 6 fused images, using the cubic resampling approach. Other images such as the fusion of SPOT 6 and CBERS, and Pleiades and RapidEye were also resampled to the cell size of $1.5 \mathrm{~m}$ during the data fusion procedure. The 2016 CBERS and 2011 RapidEye images were directly resampled to $1.5 \mathrm{~m}$ during the image-to-image registration using the nearest neighbor resampling approach. In this way, all the sensor images have the same coordinate system (i.e., UTM) and cell size $(1.5 \times 1.5 \mathrm{~m})$.

In August 2015, a field survey of land-cover types in Altamira was conducted and collected 2024 geolocalized photos. The surveyed area comprised the Altamira urban region, west to Medicilandia, and east to the Belo Monte Dam area. One third of these photos were located inside the urban region. In the summer of 2016, more field survey data were collected in the urban region. These field survey data provided the basic source for selection of training and test samples. Meanwhile, previous land-cover classification results were also collected based on Landsat images in 1991 and 2000 [30] and population census data (IBGE: http://www.ibge.gov.br/home/) for examining the relationships between population increase and land-cover dynamic changes. 


\subsection{Urban land-Cover Classification}

Before conducting land-cover classification, it is important to design a suitable classification system based on research objectives, complexity of the urban landscape, and selected remotely sensed data [4]. In this research, the land-cover types include impervious surface area (ISA), building demolition, water, pasture, bare soil, and forest/plantation. The building demolition is a special type in this research that is only available in 2015 due to removal of buildings caused by construction of new river channels and by flooded areas. Because different optical sensor data was used that had various spectral and spatial resolutions, suitable classification procedures needed to be designed for corresponding sensor data to generate the best classification accuracy. The major steps for urban land-cover classification using various data sets are illustrated in Figure 2. In this design, full use was made of the merits of different sensor data to produce accurate land-cover classification for each year. For SPOT and Pleiades images with very high spatial resolutions (0.5-1.5 m), effective use of their spatial features is critical, thus textures and segmented images were combined into the spectral bands for land-cover classification. For CBERS and RapidEye images with relatively lower spatial resolution $(5 \mathrm{~m})$, data fusion between SPOT and CBERS, and between Pleiades and RapidEye was used to improve the spatial features while preserving spectral features for non-changed area and highlighting the spectral changes for the changed areas. In order to reduce the noise problem caused by the data fusion, a median filtering approach was used for each fused image to reduce the heterogeneity in the same land covers such as tree crowns and building roofs while preserving the sharpness among different land covers.

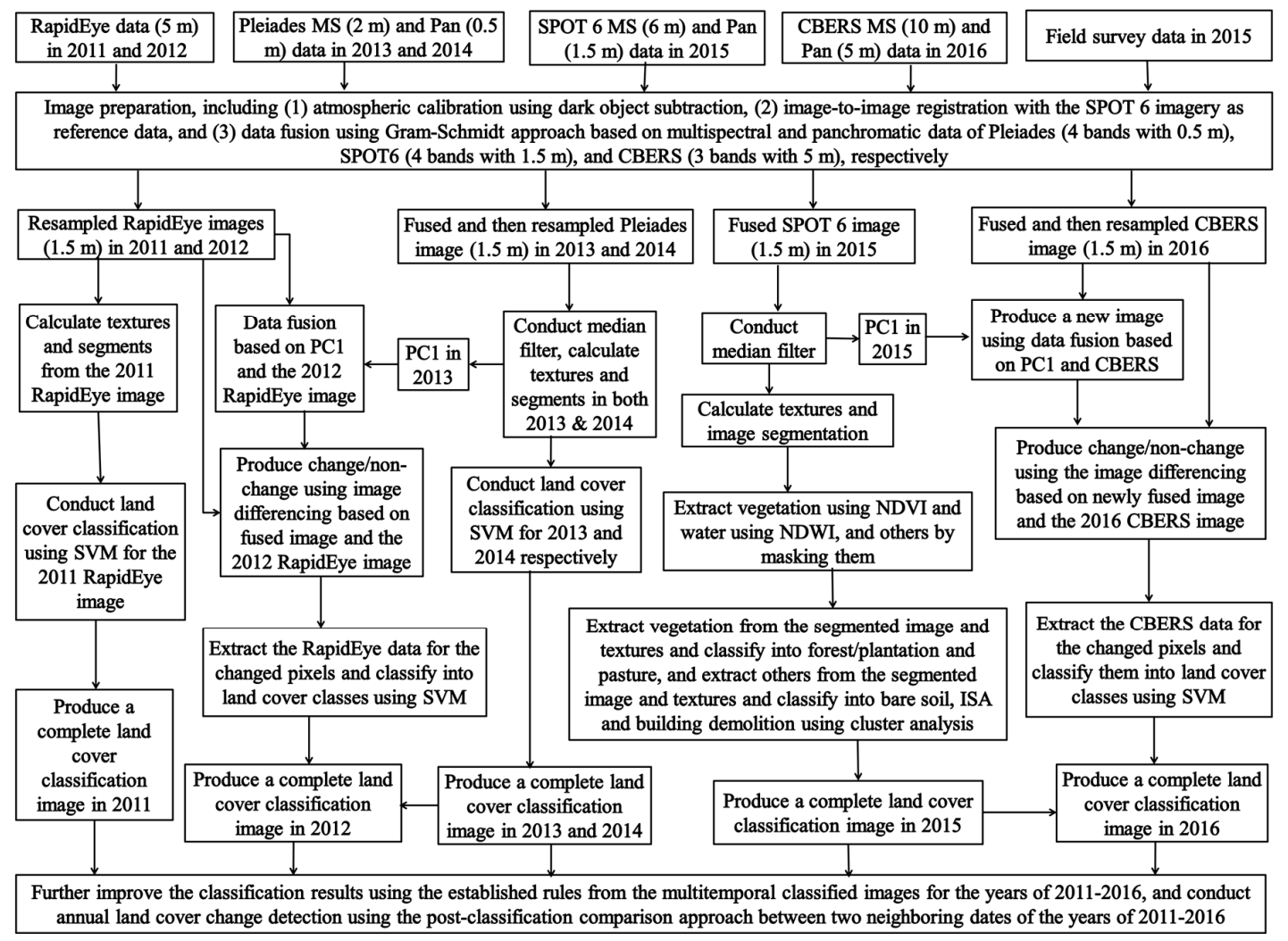

Figure 2. Framework of urban land-cover classification using a hybrid approach based on different sensor data with various spatial resolutions. MS and Pan represent multispectral and panchromatic data; SPOT represents Système Pour l'Observation de la Terre (French remote sensing satellite), CBERS represents China-Brazil Earth Resources Satellite, and PC1 represents the first principal component. SVM, support vector machine; NDVI, Normalized Difference Vegetation Index; NDWI, Normalized Difference Water Index. 
The 2015 SPOT 6 fused multispectral image with $1.5 \mathrm{~m}$ spatial resolution was first used to conduct land-cover classification because its image acquisition date coincided with the 2015 fieldwork. Textural images were extracted using dissimilarity from the SPOT green, red, and NIR spectral bands based on a window size of $7 \times 7$ pixels [44-46]. The SPOT spectral bands were also used to conduct image segmentation using the ENVI software [24,47,48]. Different parameters such as edge value, merging level, and kernel size were explored and the segmentation results were examined by visual interpretation to identify a best segmentation image. Normalized Difference Vegetation Index (NDVI) and Normalized Difference Water Index (NDWI) were then calculated from the segmented multispectral imagery [49-52]. Water was first extracted from NDWI and vegetation from NDVI using a thresholding approach, in which the threshold values were determined from training samples based on field survey data. Thus, the SPOT 6 imagery was separated into three broad categories: water, vegetation, and other land-cover classes. Vegetation includes forest/plantation and pasture; the other land-cover class includes ISA, bare soil, and building demolition. The segmented spectral images and textural images for vegetation were extracted, and cluster analysis was then used to classify these variables into 30 clusters. The analyst merged these clusters into pasture or forest/plantation based on visual interpretation and field survey data. The same procedure was used to classify the other land-cover class into bare soil, ISA, and building demolition based on cluster analysis of the extracted SPOT 6 textures and segments. Finally, different classification results (e.g., water, pasture, forest/plantation, bare soil, ISA, and building demolition) were mosaicked into a complete land-cover classification image.

A similar procedure as used in the SPOT 6 image was also used to extract textural images and segment images from the 2013 and 2014 Pleiades fused and resampled images separately. Based on the experiences from the 2015 SPOT 6 imagery and the field survey data, training samples for different land covers were selected separately from the 2013 and 2014 Pleiades images using the visual interpretation of Pleiades in its full resolution. With this very high resolution, training sample selection can be regarded as almost as good as fieldwork. Because of the wide spectral variation of the same land-cover type such as ISA, 15 land-cover classes (e.g., different ISA classes, vegetation types, and others) were initially selected. Since previous research has indicated that SVM is a good approach for land-cover classification when multisource data (e.g., spectral bands, texture and segmentation images) were used $[24,53,54]$, this classifier was also used to classify these images into 15 classes. Finally these classified land-cover classes were merged into five land-cover classes (no building demolition before 2015). A similar classification procedure was used for the 2011 RapidEye image to produce the land-cover classification result.

Spatial resolution of the 2012 RapidEye imagery $(5 \mathrm{~m})$ is much lower than Pleiades' imagery; therefore, this research adopted the data fusion approach to improve spatial resolution. The fused and resampled Pleiades multispectral imagery with $1.5 \mathrm{~m}$ cell size was transformed into three principal components using PCA. Since PC1 from the 2013 Pleiades imagery contains the most of information (over $85 \%$ ), this PC1 together with the 2012 RapidEye image was used to produce a fused imagery with cell size of $1.5 \mathrm{~m} \times 1.5 \mathrm{~m}$ using the Gram-Schmidt approach. This newly fused image and the 2012 RapidEye image (resampled to the cell size of $1.5 \mathrm{~m} \times 1.5 \mathrm{~m}$ before conducting change detection) was then used to produce the change and no-change categories using the thresholding approach based on the differencing image of NIR bands at two dates (see Figure 2). The variables (spectral, texture, segments) for changed pixels were extracted and SVM was used for land-cover classification, from which the training samples were selected by visual interpretation using color composition of Pleiades imagery at its original $0.5 \mathrm{~m}$ pixel spacing. The final classification results were combined from the classified image of changed pixels and those from the 2013 classified images with no-change pixels. This similar procedure was used for the 2016 CBERS images for land-cover classification. A majority filter with a window size of $3 \times 3$ pixels was finally used to reduce the "salt-and-pepper" for all classified images between 2011 and 2016. These classified images were overlaid on the color composite to make sure no land covers were obviously misclassified. 


\subsection{Urban Land-Cover Change Detection}

Although many change detection approaches are available $[9,10,26]$, most of these technologies can only provide change and non-change information [9]. The post-classification comparison approach is often used for conducting the detection of land-cover change trajectories [8]. In particular, this research used different sensor data for examining urban land-cover change, thus the post-classification comparison may be the best approach for providing the trajectories. One critical step in this approach is to develop highly accurate classification images for each date. In this research, the land-cover classification results were developed using the hybrid approach based on high spatial resolution images, as described above. Based on our field survey, the land-cover change system will mainly focus on the following: ISA increase (conversion from pasture, bare soil, or forest) and ISA decrease (to building demolition or water, only for 2015 and 2016), water change (from or to bare soil, or from building demolition), pasture increase (from bare soil or forest) and decrease (to bare soil or ISA), bare soil increase (conversion from pasture or forest) or decrease (to pasture, plantation, or water), and forest/plantation decrease (to bare soil, pasture, or ISA). The change detection was conducted annually between 2011 and 2016. Because of the registration errors between multitemporal images, pixel-based change detection results often produce some unreasonable change trajectories, such as from ISA to forest within one year, thus these pixels were recoded as no-change category.

In addition to annual land-cover change analysis between 2011 and 2016, the annual changes were also compared with previous land-cover change in 1991-2011 based on the results from Landsat images [30]. Here we defined annual average changed area $\left(\mathrm{km}^{2} /\right.$ year $)=\left(X_{j}-X_{i}\right) /(j-i)$; and annual average changed area rate $(\%)=\frac{1}{(j-i)}\left(\frac{X_{j}-X_{i}}{X_{i}}\right) * 100$, where $X_{i}$ and $X_{j}$ are the areas of a specific land cover at initial year $i$ and post year $j$. The change detection results were related to population in the same periods to better understand the impacts of dam construction-induced activities on land-cover change near Altamira city.

\subsection{Accuracy Assessment}

For land-cover classification or change detection, accuracy assessment is an important part and the error matrix is often used $[55,56]$. The major steps for accuracy assessment include determination of number of test samples, sampling approach, identification of land-cover type for each sample plot, and calculation of classification or change detection accuracy based on the established error matrix. From the error matrix, overall classification accuracy and kappa coefficients can be calculated to evaluate the overall performance in a classified image; meanwhile, user's accuracy and producer's accuracy were calculated for assessing the classification performance of each land-cover class [55,56]. In this research, a total number of 300 test sample plots were selected and allocated with the stratified random sampling approach for each classified image. Several co-authors had visited this study area in 2015 and 2016 for conducting a field survey and collecting a large number of sample plots to be used as test samples for accuracy assessment. For other years, the high spatial resolution images were visually interpreted to collect test samples. Co-author Dr. Calvi has lived and worked in Altamira for many years and knows this study area well. He came to Michigan State University as a visiting scholar for three months, joining the research team. He provided assistance in identifying land-cover types for each test sample plot. The accuracy assessment was only conducted for the land-cover classification, not for change detection because the change detection results depend on the classification results and image-to-image registration accuracy, which are assumed to be good enough for this research if the classification accuracy meets the requirement.

\section{Results}

\subsection{Analysis of Urban Land-Cover Distribution and Dynamic Changes}

The accuracy assessment results (Table 2) indicate that urban land-cover classification results have overall accuracies of $90-92 \%$ and kappa coefficients of $0.85-0.90$. This high accuracy for each 
classification image meets the requirement for further conducting land-cover change detection. Table 2 indicates that major classification errors are from the confusion between bare soil and pasture, between ISA and bare soil, and between pasture and new plantations. These confusions are reasonable because of their similar spectral signatures during the dry season, as previous research has confirmed [15,57]. The bare soil class in 2011 and 2012 has especially low accuracies with user's accuracies of only $56.3 \%$ and $60.9 \%$, probably because of its relatively low spatial resolution in RapidEye imagery compared to Pleiades, resulting in more confusion of spectral signatures among bare soil, ISA, and pasture. The spatial distribution of land-cover classes in Figure 3 indicates that pasture and forest/plantation have the largest area distribution, and ISA increases obviously, especially in the southwestern and northern parts. Building demolition mainly occurred in the flooded areas along the river in 2015. Another obvious spatial pattern is the increased water bodies along the Xingu River in 2016.

Table 2. Accuracy assessment of urban land-cover classification results in 2011-2016.

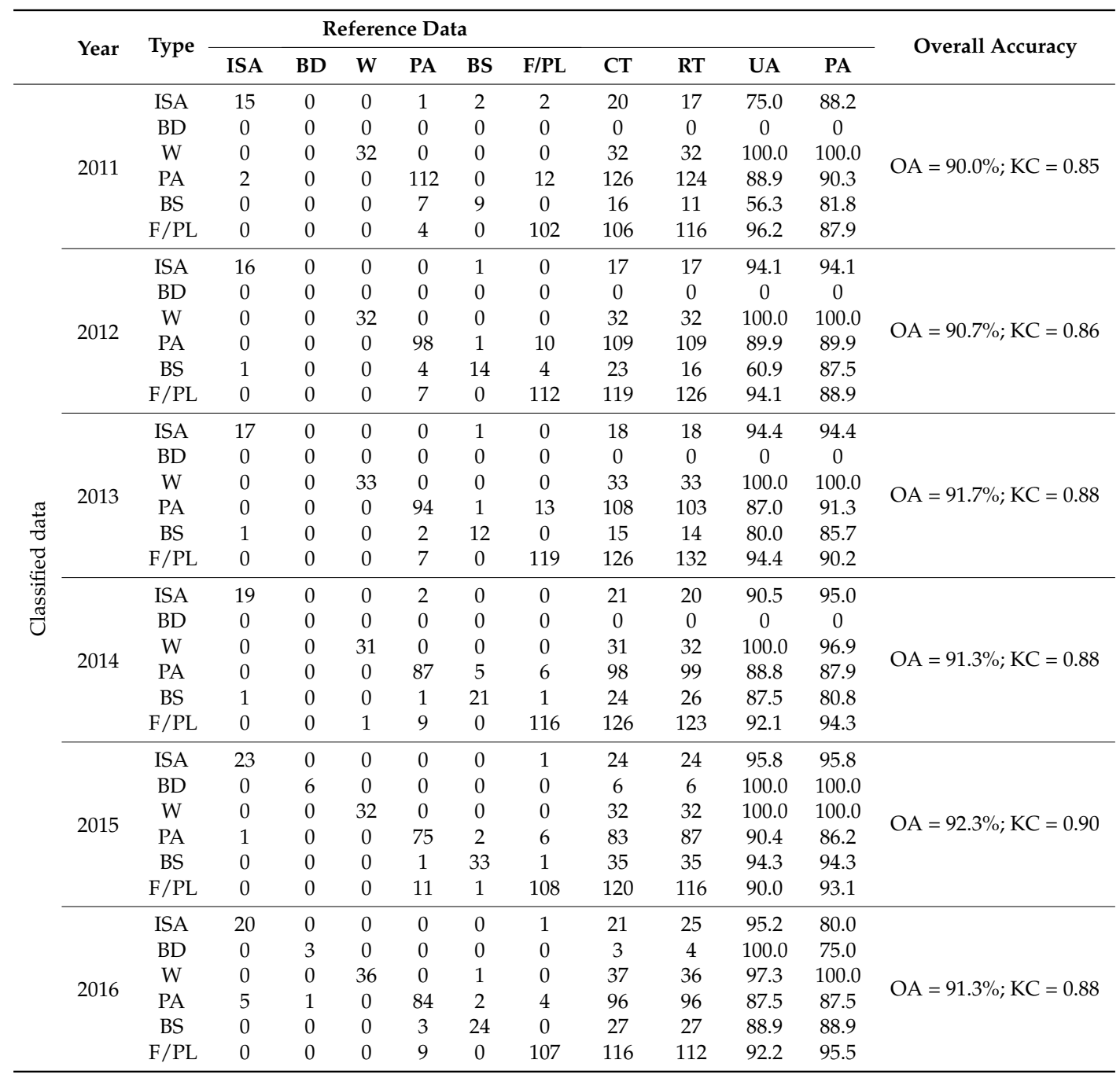

Note: ISA, impervious surface area; BD, building demolition (available only in 2015 and 2016); W, water; PA, pasture; $\mathrm{BS}$, bare soil; F/PL, forest/plantation; CT, column total; RT, row total; UA, user's accuracy; PA, producer's accuracy; $\mathrm{OA}$, overall classification accuracy; KC, kappa coefficient.

The statistical results in Table 3 indicate that forest/plantation and pasture accounted for the largest area (37.7-43.9\% for forest and 29.4-38.5\% for pasture from 2011 to 2016), ISA and bare soil had relatively small areas, and building demolition occurred only in 2015 and 2016 in a very small proportion of the total area. Overall, ISA increased continuously from 5.9\% in 2011 to $8.6 \%$ in 2016; 
water remained stable until 2016, increasing by 2.4\% from 2015 to 2016; pasture decreased continuously from $38.5 \%$ in 2011 to $29.4 \%$ in 2015 , but increased in 2016 due to the conversion of bare soil to pasture; while forest/plantation slightly increased from 41.1\% to 43.9\% from 2011 to 2013, then decreased continuously to $37.7 \%$ in 2016 . Bare soil area remained relatively small in the first three years, and then increased to $8.2-11.8 \%$ in the last three years.

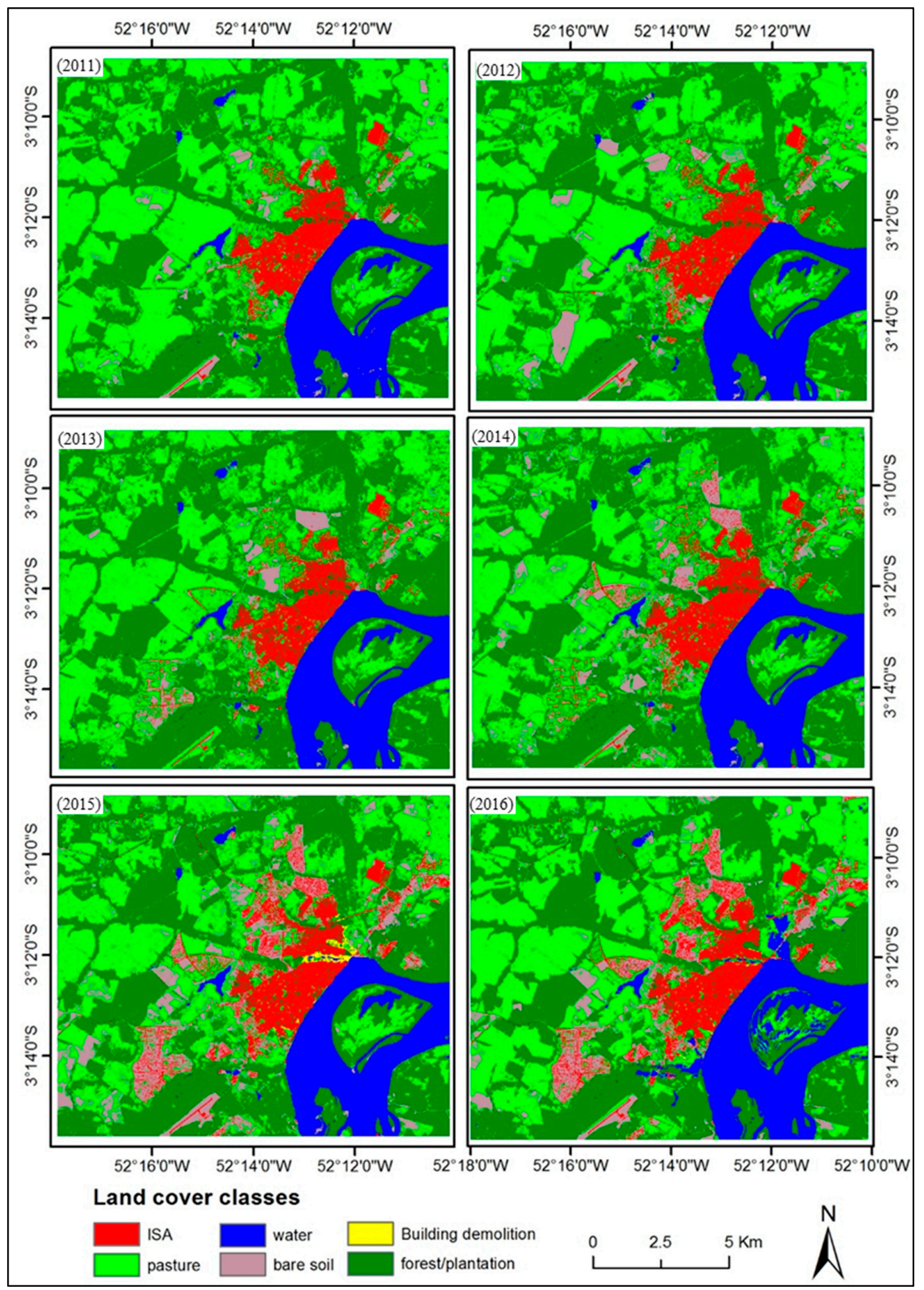

Figure 3. Urban land-cover distribution annually from 2011 to 2016, showing forest and pasture distribution in a large area. 
Table 3. Statistical results of land-cover areas and percentages in 2011-2016.

\begin{tabular}{ccccccc}
\hline \multicolumn{7}{c}{ Area $\mathbf{( k m}^{2}$ ) of Each Land Cover in Various Years } \\
\hline Land Cover & $\mathbf{2 0 1 1}$ & $\mathbf{2 0 1 2}$ & $\mathbf{2 0 1 3}$ & $\mathbf{2 0 1 4}$ & $\mathbf{2 0 1 5}$ & $\mathbf{2 0 1 6}$ \\
\hline ISA & 10.45 & 10.58 & 10.98 & 12.54 & 14.79 & 15.33 \\
W & 19.34 & 19.43 & 19.71 & 19.38 & 19.47 & 23.65 \\
PA & 68.45 & 63.88 & 60.87 & 57.62 & 52.27 & 57.22 \\
BS & 6.55 & 9.88 & 8.28 & 15.51 & 21.03 & 14.55 \\
F/PL & 73.15 & 74.15 & 78.09 & 72.88 & 69.76 & 67.1 \\
BD & \multicolumn{5}{c}{0.61} & 0.09 \\
\hline \multicolumn{6}{c}{ Percent (\%) of Each Land Cover Accounting for Total Area } \\
\hline Land Cover & $\mathbf{2 0 1 1}$ & $\mathbf{2 0 1 2}$ & $\mathbf{2 0 1 3}$ & $\mathbf{2 0 1 4}$ & $\mathbf{2 0 1 5}$ & $\mathbf{2 0 1 6}$ \\
\hline ISA & 5.87 & 5.95 & 6.17 & 7.05 & 8.31 & 8.62 \\
W & 10.87 & 10.92 & 11.08 & 10.89 & 10.94 & 13.29 \\
PA & 38.47 & 35.9 & 34.21 & 32.38 & 29.38 & 32.16 \\
BS & 3.68 & 5.55 & 4.65 & 8.72 & 11.82 & 8.18 \\
F/PL & 41.11 & 41.68 & 43.89 & 40.96 & 39.21 & 37.71 \\
BD & \multicolumn{5}{c}{0.34} & 0.05
\end{tabular}

Note: ISA, impervious surface area; BD, building demolition; $\mathrm{W}$, water; PA, pasture; $\mathrm{BS}$, bare soil; F/PL, forest/plantation.

Table 4 indicates that from 2011 to 2016 pasture and forest decreased while ISA, bare soil, and water increased. Specifically, the first year (2011-2012) witnessed a decrease of pasture and increase of bare soil; the second year (2012-2013) witnessed decreases of pasture and bare soil and an increase of forest/plantation; the third and fourth years (i.e., 2013-2014 and 2014-2015) witnessed decreases of pasture and forest/plantation, and increases of bare soil and ISA. In the fifth year, the major decreases were bare soil and forest/plantation and major increases were water and pasture. Table 4 indicates that pasture, bare soil, and forest/plantation were the major land-cover changes from 2011 to 2015. When the dam construction was almost finished, pasture and water increased at the cost of bare soil and forest/plantation. One special class in this study area is the increased area of building demolition due to the construction of new channels and impacts of lowland waters in 2015; then the area of building demolition decreased in 2016 due to inundation in the lowland region along the rivers. Table 4 also indicates ISA continued to increase from 2011 to 2015 but the increased area became small after 2015 due to the completed residential neighborhood projects.

Table 4. Changed area of each land cover and proportion of each changed land cover accounting for the total changed area in each one-year period.

\begin{tabular}{|c|c|c|c|c|c|c|}
\hline \multirow{2}{*}{ Type } & \multirow{2}{*}{$2011-2016\left(\mathrm{~km}^{2}\right)$} & \multicolumn{5}{|c|}{ Changed Area $\left(\mathrm{km}^{2}\right)$ of Land Covers in One-Year Periods } \\
\hline & & 2011-2012 & 2012-2013 & 2013-2014 & 2014-2015 & 2015-2016 \\
\hline ISA & 4.88 & 0.13 & 0.40 & 1.56 & 2.25 & 0.54 \\
\hline W & 4.31 & 0.09 & 0.28 & -0.33 & 0.09 & 4.18 \\
\hline PA & -11.23 & -4.57 & -3.01 & -3.25 & -5.35 & 4.95 \\
\hline BS & 8.00 & 3.33 & -1.60 & 7.23 & 5.52 & -6.48 \\
\hline $\mathrm{F} / \mathrm{PL}$ & -6.05 & 1.00 & 3.94 & -5.21 & -3.12 & -2.66 \\
\hline $\mathrm{BD}$ & 0.09 & & & & 0.61 & -0.52 \\
\hline \multirow{2}{*}{ Type } & \multirow{2}{*}{$2011-2016(\%)$} & \multicolumn{5}{|c|}{ Percent (\%) of Each Changed Land Cover Accounting for Total Changed Area } \\
\hline & & 2011-2012 & 2012-2013 & 2013-2014 & 2014-2015 & 2015-2016 \\
\hline ISA & 14.12 & 1.43 & 4.33 & 8.87 & 13.28 & 2.79 \\
\hline W & 12.47 & 0.99 & 3.03 & 1.88 & 0.53 & 21.62 \\
\hline PA & -32.49 & -50.11 & -32.61 & -18.49 & -31.58 & 25.61 \\
\hline BS & 23.15 & 36.51 & -17.33 & 41.13 & 32.59 & -33.52 \\
\hline $\mathrm{F} / \mathrm{PL}$ & -17.51 & 10.96 & 42.69 & -29.64 & -18.42 & -13.76 \\
\hline BD & 0.26 & & & & 3.60 & -2.69 \\
\hline
\end{tabular}

Note: ISA, impervious surface area; $\mathrm{BD}$, building demolition; $\mathrm{W}$, water; PA, pasture; $\mathrm{BS}$, bare soil; $\mathrm{F} / \mathrm{PL}$, forest/plantation. 


\subsection{Analysis of Urban Land-Cover Change Trajectories}

Figure 4 illustrates the spatial distribution of major land-cover dynamic change. Overall, ISA increased (Figure 4(a1)) obviously from 2011 to 2016 with clear spatial patterns, and ISA decreased (Figure 4(a2)) limitedly. Specifically, ISA had small increased areas around the urban frontiers in 2011-2012, but in the next three years (2012-2015), ISA increased rapidly, forming several new neighborhoods in the southwest, west, north, and northeast, in addition to the areas around the original urban region (see Figure 4(a1)). The ISA increased area was sharply reduced in 2015-2016. Major ISA loss occurred in 2014-2015 due to the building demolition caused by changes to channels in 2015 and in 2015-2016 along the Xingu River where the increased water bodies caused by the finished dam construction inundated the lowland areas (see Figure 4(a2)). Water dynamic change was very limited before 2015 (Figure 4(b1,b2)), but water area considerably increased in 2015-2016 (see Figure 4(b1)) due to the finished dam construction in 2016.

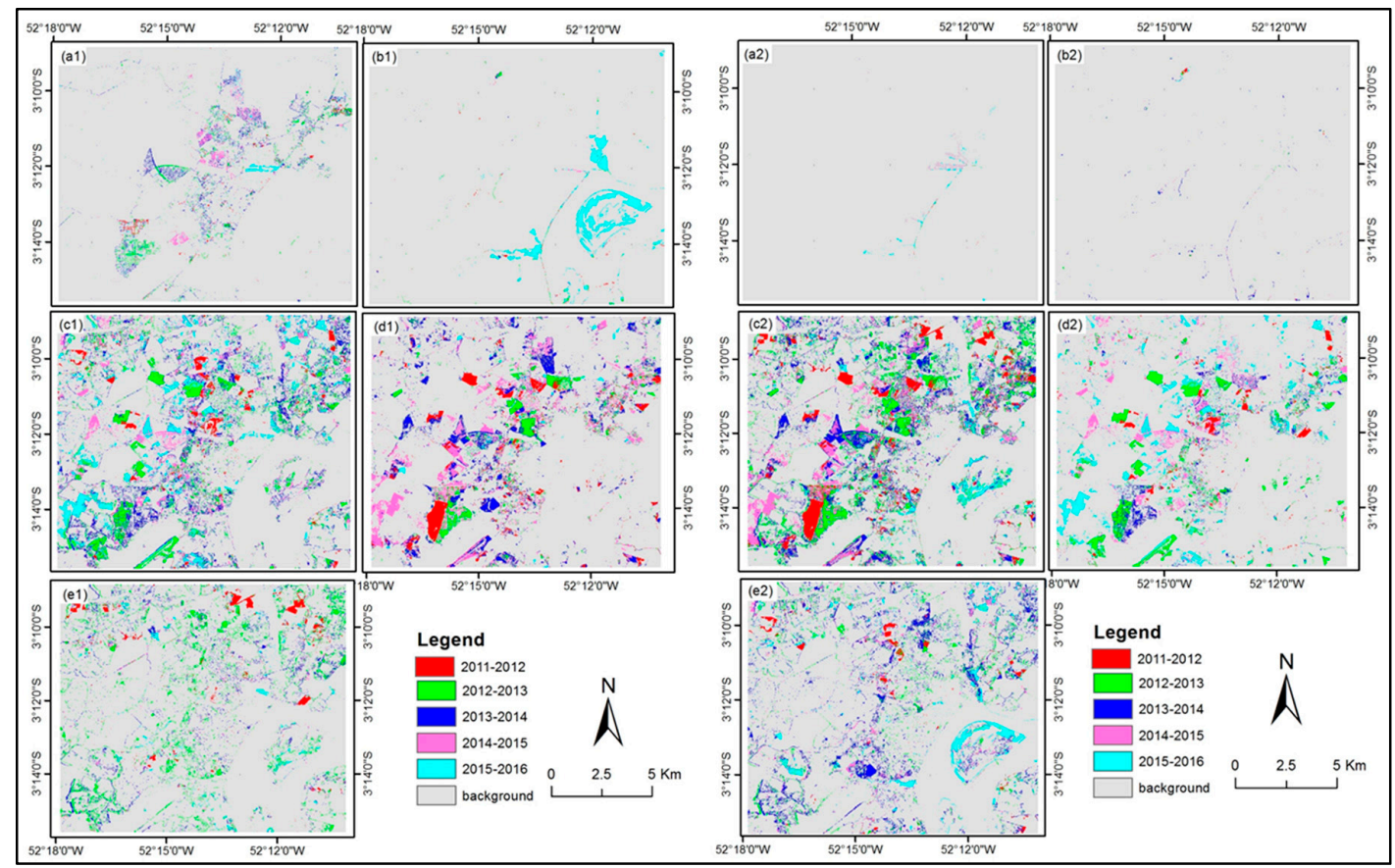

Figure 4. Spatial distribution of annual urban land-cover dynamic change from 2011 to 2016; (a-e) are graphics of ISA, water, pasture, bare soil, forest/plantation, respectively; 1 and 2 represent increased area and lost area, respectively.

Figure 4 also indicates that during 2011-2016 pasture gain (Figure 4(c1)) and loss (Figure 4(c2)) accounted for a large area with clear spatial patterns of major changes in the southwest, north, and northeast, as well as around the original urban region, while the bare soil gain (Figure 4(d1)) and loss (Figure 4(d2)) were mainly located around the urban region. A comparison of the dynamic changes between pasture (Figure 4(c1,c2)) and bare soil (Figure $4(\mathrm{~d} 1, \mathrm{~d} 2))$ showed similar spatial patterns between pasture gain (Figure 4(c1)) and bare soil loss (Figure 4(d2)) and between bare soil gain (Figure 4(d1)) and pasture loss (Figure 4(c2)). Specifically, pasture gained very small in 2011-2012 and a small part of the gain coincided with bare soil loss (Figure 4(c1) vs. Figure 4(d2)), but bare soil gain matched well with pasture loss (Figure 4(d1) vs. Figure 4(c2)), implying the obvious conversion from pasture to bare soil in this period. In 2012-2013, many patches of pasture gain coincided with the bare soil loss (Figure 4(c1) vs. Figure 4(d2)) and relatively small areas of bare soil gain coincided with pasture loss (Figure 4(d1) vs. Figure 4(c2)), implying high conversion between bare soil and pasture. Other pasture and bare soil areas that did not match were converted to ISA. In 2013-2014, many patches of bare soil gain coincided with pasture loss, and very limited area of pasture gain 
and bare soil loss was matched, implying a major conversion from pasture to bare soil in this period. In 2014-2015, an obvious change was that a large proportion of bare soil gain coincided with pasture loss, which reversed in 2015-2016. The change of forest/plantation (see Figure 4(e1,e2)) was scattered in different parts of this study area without clear spatial patterns. In 2011-2012, plantation gain was mainly located in the northeast (Figure 4(e1)), and deforestation occurred along the urban boundary (Figure 4(e2)). Obvious changes were the plantation gain in 2012-2013 and deforestation in 2013-2014 and 2015-2016.

Table 4 only provided the overall change of each land cover, but cannot tell the detailed change trajectories. Through analyzing the post-classification comparison results as summarized in Table 5, we can better understand land-cover change trajectories in different periods. During the overall detection period (2011-2016), ISA, water, and bare soil had much larger increased areas than decreased areas, but pasture and forest/plantation were opposite. Table 5 also indicates that the dynamic changes of these land covers were not balanced in different years. For example, the ISA gain was mainly due to the conversion from pasture during 2011-2014 and from bare soil in the last two years (2014-2016). The ISA loss area was mainly due to the building demolition in 2014-2015. Pasture and bare soil had high conversion rates each other. Pasture was converted to bare soil from 2011 to 2015, and bare soil was converted to pasture in 2012-2013 and 2015-2016. Deforestation was obvious during 2012-2015, but there was also some afforestation, especially the conversion from pasture to new plantations between 2012 and 2014.

Table 5. Statistical results $\left(\mathrm{km}^{2}\right)$ of land-cover change trajectories.

\begin{tabular}{|c|c|c|c|c|c|c|c|}
\hline \multicolumn{2}{|c|}{ Land-Cover Change Trajectories } & 2011-2016 & 2011-2012 & 2012-2013 & 2013-2014 & 2014-2015 & 2015-2016 \\
\hline \multirow{7}{*}{ ISA change } & PA-ISA & 4.00 & 0.33 & 1.09 & 1.70 & 0.48 & 0.11 \\
\hline & BS-ISA & 0.63 & 0.09 & 0.51 & 0.39 & 1.09 & 0.43 \\
\hline & Non(PA, BS)-ISA & 1.56 & 0 & 0.01 & 0.02 & 0.01 & 0.19 \\
\hline & Gain & 6.19 & 0.42 & 1.61 & 2.11 & 1.58 & 0.73 \\
\hline & ISA-BD & 0.09 & 0 & 0.00 & 0.00 & 0.61 & 0.09 \\
\hline & ISA-Non(BD) & 0.79 & 0.01 & 0.02 & 0 & 0.03 & 0.12 \\
\hline & Loss & 0.88 & 0.01 & 0.02 & 0 & 0.64 & 0.21 \\
\hline \multirow{6}{*}{ Water change } & BS-W & 0.57 & 0.10 & 0.12 & 0 & 0.02 & 0.58 \\
\hline & Non(BS)-W & 3.89 & 0.05 & 0.13 & 0.06 & 0.03 & 3.62 \\
\hline & Gain & 4.46 & 0.15 & 0.25 & 0.06 & 0.05 & 4.20 \\
\hline & W-BS & 0.02 & 0.04 & 0.01 & 0.14 & 0.03 & 0.01 \\
\hline & W-Non(BS) & 0.07 & 0.01 & 0.06 & 0.12 & 0.06 & 0.01 \\
\hline & Loss & 0.09 & 0.05 & 0.07 & 0.26 & 0.09 & 0.02 \\
\hline \multirow{8}{*}{ Pasture change } & BS-PA & 2.32 & 1.28 & 5.53 & 2.6 & 4.58 & 6.41 \\
\hline & F/PL-PA & 5.56 & 1.10 & 4.01 & 7.55 & 3.67 & 1.99 \\
\hline & Non(BS, F/PL)-PA & 0.39 & 0.01 & 0.05 & 0.10 & 0.05 & 0.31 \\
\hline & Gain & 8.27 & 2.39 & 9.59 & 10.25 & 8.30 & 8.71 \\
\hline & PA-BS & 10.54 & 4.70 & 4.40 & 8.27 & 11.57 & 0.82 \\
\hline & PA-F/PL & 3.54 & 1.67 & 7.71 & 4.10 & 1.60 & 1.45 \\
\hline & PA-Non(BS, F/PL) & 1.45 & 0.37 & 1.20 & 1.76 & 0.48 & 1.68 \\
\hline & Loss & 15.53 & 6.74 & 13.31 & 14.13 & 13.65 & 3.95 \\
\hline \multirow{7}{*}{ Bare soil change } & PA-BS & 10.54 & 4.70 & 4.40 & 8.27 & 11.57 & 0.82 \\
\hline & Non(PA)-BS & 1.52 & 0.19 & 0.42 & 1.88 & 0.13 & 0.26 \\
\hline & Gain & 12.06 & 4.89 & 4.82 & 10.15 & 11.70 & 1.08 \\
\hline & BS-PA & 2.32 & 1.28 & 5.53 & 2.60 & 4.58 & 6.41 \\
\hline & $\mathrm{BS}-\mathrm{F} / \mathrm{PL}$ & 0.39 & 0.42 & 0.50 & 0.22 & 0.38 & 0.09 \\
\hline & BS-Non(PA, F/PL) & 1.20 & 0.19 & 0.63 & 0.39 & 1.11 & 1.01 \\
\hline & Loss & 3.91 & 1.89 & 6.66 & 3.21 & 6.07 & 7.51 \\
\hline \multirow{6}{*}{$\begin{array}{c}\text { Forest/plantation } \\
\text { change }\end{array}$} & PA-F/PL & 3.54 & 1.67 & 7.71 & 4.10 & 1.60 & 1.45 \\
\hline & Non(PA)-F/PL & 0.39 & 0.42 & 0.50 & 0.22 & 0.38 & 0.09 \\
\hline & Gain & 3.93 & 2.09 & 8.21 & 4.32 & 1.98 & 1.54 \\
\hline & F/PL-PA & 5.56 & 1.10 & 4.01 & 7.55 & 3.67 & 1.99 \\
\hline & F/PL-Non(PA) & 5.04 & 0.15 & 0.41 & 1.74 & 0.10 & 2.23 \\
\hline & Loss & 10.60 & 1.25 & 4.42 & 9.29 & 3.77 & 4.22 \\
\hline
\end{tabular}

Notes: ISA, impervious surface area; BD, building demolition; W, water; PA, pasture; BS, bare soil; F/PL, forest/plantation. Non( class $_{1}$, class 2 ) means all classes but class 1 and class $_{2}$. 


\subsection{The Impacts of Belo Monte Dam Construction on Altamira's Urban Land-Cover Change}

This research shows the rapid changes in urban land covers, especially the increase of ISA, and the dynamic change between pasture and bare soil due to the Belo Monte dam construction between 2011 and 2016. Based on our previous research using Landsat imagery [30] and current results using high spatial resolution images, we reorganized the classification system into four categories: forest/plantation, pasture, ISA, and water and calculated their areas in 1991, 2000, 2011, and 2016 to examine their changes and corresponding population data (see Table 6). It indicates that annual forest and pasture loss areas after 2011 were much higher than those before 2011; in contrast, annual ISA and water areas gained were much higher after 2011 than those before 2011. This situation coincided with the population growth rate in the same period. This further confirmed that the rapid population increase due to Belo Monte dam construction was the major factor resulting in the rapid urban expansion at the cost of pasture and forest loss. If the annual deforestation area between 2011 and 2016 had been the same as in the preceding decade (2000-2011), it would be found that $50 \%$ of the increased annual deforestation area could be attributed to the Belo Monte dam construction.

Table 6. A comparison of major land-cover data and corresponding population data in the same periods.

\begin{tabular}{|c|c|c|c|c|c|c|c|c|c|c|}
\hline \multirow{2}{*}{ Type } & \multicolumn{4}{|c|}{ Area $\left(\mathrm{km}^{2}\right)$} & \multicolumn{3}{|c|}{$\begin{array}{c}\text { Annual Average Changed Area } \\
\left(\mathrm{km}^{2} / \text { Year }\right)\end{array}$} & \multicolumn{3}{|c|}{$\begin{array}{c}\text { Annual Average Changed Area } \\
\text { Rate (\%) }\end{array}$} \\
\hline & 1991 & 2000 & 2011 & 2016 & 2000-1991 & 2011-2000 & 2016-2011 & 2000-1991 & 2011-2000 & 2016-2011 \\
\hline FP & 80.10 & 82.19 & 73.21 & 67.07 & 0.23 & -0.82 & -1.23 & 0.29 & -0.99 & -1.68 \\
\hline PA & 65.99 & 63.17 & 65.83 & 57.40 & -0.31 & 0.24 & -1.69 & -0.47 & 0.38 & -2.56 \\
\hline ISA & 12.11 & 12.72 & 13.13 & 15.38 & 0.07 & 0.04 & 0.45 & 0.56 & 0.29 & 3.43 \\
\hline \multirow[t]{3}{*}{ Water } & 19.91 & 20.02 & 19.32 & 23.61 & 0.01 & -0.06 & 0.86 & 0.06 & -0.32 & 4.44 \\
\hline & \multicolumn{4}{|c|}{ Number of Persons } & \multicolumn{3}{|c|}{$\begin{array}{l}\text { Annual Average Population } \\
\text { Growth (Person/Year) }\end{array}$} & \multicolumn{3}{|c|}{$\begin{array}{c}\text { Annual Average Population } \\
\text { Growth Rate (\%) }\end{array}$} \\
\hline & 1991 & 2000 & 2010 & 2012 & 2000-1991 & $2010-2000$ & 2012-2010 & 2000-1991 & $2010-2000$ & 2012-2010 \\
\hline Pop & 50,145 & 62,285 & 77,195 & 150,000 & 1349 & 1491 & 36,403 & 2.69 & 2.39 & 47.16 \\
\hline
\end{tabular}

Considering four land-cover categories-forest/plantation, pasture, ISA, and water-the major land-cover changes were the conversions from forest to pasture or ISA, and pasture to ISA. Table 7 summarizes the average annual changed area in the three stages. The annual changed areas during 1991-2000 and 2000-2011 were similar; however, after 2011, the annual change area from forest to pasture sharply decreased from about $1.9 \mathrm{~km}^{2}$ to $1.1 \mathrm{~km}^{2}$, while the annual conversion from pasture to ISA increased rapidly from $0.12-0.13 \mathrm{~km}^{2}$ before 2011 to $0.46 \mathrm{~km}^{2}$ after 2011. Meanwhile, during dam construction, some forest/plantation was also converted to bare soil and water, especially forest that was inundated after the dam construction was finished, as shown in Table 5. This big difference in land-cover conversion rate before and after 2011 was due to the influence of Belo Monte dam construction on the urban land-cover change in Altamira. As shown in Figure 1, the water body in the dam construction area in 2016 was much larger than before, resulting in considerable change in some urban regions of Altamira where buildings in the lowlands along the river had to be removed and a large area of urban expansion on the other side of Xingu River occurred due to the rapidly increasing population for the dam construction. This rapid land-cover change in Altamira produced new challenges for improving management of urban and rural areas. Other challenges, such as flooding due to heavy storms and extreme drought problems, may appear in the future. 
Table 7. A comparison of annual changed areas of the major land-cover change trajectories among different change periods.

\begin{tabular}{cccc}
\hline \multirow{2}{*}{ Change Trajectories } & \multicolumn{3}{c}{ Average Annual Changed Area $\mathbf{( k m}^{\mathbf{2}} \mathbf{~}$} \\
\cline { 2 - 4 } & $\mathbf{1 9 9 1 - 2 0 0 0}$ & $\mathbf{2 0 0 0 - 2 0 1 1}$ & $\mathbf{2 0 1 1 - 2 0 1 6}$ \\
\hline Forest/plantation to Pasture & 1.92 & 1.94 & 1.11 \\
Forest/plantation to Bare soil & & & 0.24 \\
Forest/plantation to Water & & & 0.45 \\
Forest/plantation to ISA & 0.06 & 0.08 & 0.31 \\
Pasture to ISA & 0.12 & 0.13 & 0.46 \\
\hline
\end{tabular}

\section{Discussion}

Remote sensing-based change detection studies usually require multitemporal data to have the following characteristics: using the same sensor data to reduce the difference in spectral, spatial, and radiometric resolutions, and similar image acquisition dates to reduce the difference in land surface reflectance caused by vegetation phenology, sun elevation, and azimuth angles [9]. However, frequent cloud covers in moist tropical regions cannot meet the requirement of change detection approaches. To overcome this problem, there are two possible solutions: using the all-weather radar data alone [58] and using a combination of different sensor data such as radar and optical images [59]. The drawback is the lower discriminability power in radar data, resulting in poor classification or change detection of land covers [57]. In general, optical sensor data can provide a finer land-cover classification system with higher classification accuracy than radar data alone [54]. In order to use solely optical sensor images for land-cover change detection, one has to find, within the intended time period, whatever optical data are available, with the necessary minimum required resolution. In previous research, the satellite images such as Landsat and SPOT with spatial resolution of 10-30 m were often used, but considering the complex composition of urban land covers, higher spatial resolution optical sensor data are required [12]. Lu et al. [13] addressed this problem and concluded that pixel-based methods on Landsat images overestimated ISA by $50-60 \%$ in a small city in Brazil. Fractional estimates mitigated the problem, but use of higher resolution images was necessary to calibrate these fractional estimates.

The satellite images such as Worldview, QuickBird, IKONOS, and Pleiades have multispectral data with spatial resolution of 2-4 $\mathrm{m}$ and one panchromatic band with sub-meter resolution. In order to effectively use multispectral and panchromatic data with different spatial resolutions, data fusion is often used to improve spatial features through integration of multispectral and panchromatic data for improvement of visual interpretation, or to improve land-cover classification [38,39]. Although different data fusion approaches can be used, improper use of the fusion approach may considerably distort the spectral features, resulting in poor classification accuracy $[40,41]$. Special caution should be taken for the data fusion of high spatial resolution images because too great a heterogeneity of the land covers in the fusion image will produce new difficulties for quantitative analysis. This research indicated that filtering on the fusion image is helpful in reducing the heterogeneity problem. Current data fusion approaches are based on multispectral data and one band with higher spatial resolution, more research should be done in developing the approaches that can fuse both multispectral data with different spatial resolutions.

In addition to using data fusion techniques to improve land-cover classification accuracy, data fusion of different dates of images can also be used for land-cover change detection [60]. However, the fusion of multiple sensor data with different spectral, spatial, and temporal features makes the fusion results much more complex for quantitative analysis. For the high spatial resolution images, ground truth data with temporal information are needed for developing a suitable change detection approach. In recent decades, the object-based change detection techniques have been explored $[9,61,62]$. Use of data fusion-based approaches for land-cover change detection will be a new 
research direction [63] because of the easy availability of different sensor data in the future. This is especially valuable in moist tropical regions due to the difficulty in collecting the same satellite sensor data on different dates. This research explored the Gram-Schmidt approach to integrate two different sensor data with various image acquisition dates for land-cover change and non-change detection. More research is needed to effectively integrate both multiple spectral bands with different dates so that rich land-cover change information can be highlighted.

For high spatial resolution images, spectral features cannot be effectively used to separate different land-cover types using pixel-based classification approaches [15]. The major reasons may be large spectral variation within the same land-cover type, and the spectral confusion of different land covers such as ISA, bare soil, water, and shadows cast by tall objects. Previous research has indicated that incorporation of spatial features into spectral data is needed to improve land-cover classification $[15,64]$. This research used textures and segments in the multispectral bands for land-cover classification in an urban region and confirmed the effectiveness using spatial information from high spatial resolution satellite images. For a high spatial resolution image, full use can be made of spectral, textural, and segmented features for improving land-cover classification. However, if multiple sensor data are used for land-cover change detection, its high spatial resolution may generate new challenges for detecting land-cover change due to the unique characteristics indicated in the introduction. One critical problem is the displacements caused by different image acquisition dates [14]; thus, different sun elevation angles and azimuth angles will produce different displacements, sizes, and shapes of shadows cast by tall objects. To date, no effective approaches are available to solve this problem.

Urban land-cover distribution and its dynamic changes are important data sources for making better decisions on urban planning and management. However, the rapid increase of population and related high change of urban land covers, including the rapid urban expansion in this study, produced many new challenges such as social safety, human health, food and energy supplies, and ecosystem environments. More research is needed to examine how the dam construction project directly or indirectly affects the urban planning and functions in Altamira, and how the newcomers adapt to their new environment.

\section{Conclusions}

Automatic change detection in urban landscapes using high spatial resolution images is a challenge, especially when different sensor data are used, because of the unique spectral and spatial characteristics. This research proposed a hybrid approach for specific sensor data to produce highly accurate urban land-cover classification results. This research has shown that the incorporation of spatial features into multispectral data from high spatial resolution satellite images is needed for improving land-cover classification in urban landscapes. It is necessary to design a suitable classification approach corresponding to specific remote sensing data instead of using conventional approaches based on training samples and multispectral features. The classification accuracy of over $90 \%$ for six urban land-cover classes were obtained in the urban landscape of the moist tropical region. The high classification accuracy provided the fundamental data source for further examining land-cover change detection in this study area. One critical change in this study is the rapid ISA expansion at the cost of pasture, bare soil, and forest loss. Comparison of the annual land-cover conversion areas before and after 2011, forest and pasture have much higher loss, while ISA and water have much higher gain after 2011 than before. About 50\% of the increased annual deforestation area can be attributed to the dam construction, resulting in increased conversion from forest to bare soil and ISA in Altamira. The rapid population increase in a short period due to the Belo Monte dam construction is an important factor resulting in rapid urban land-cover change, generating new challenges in urban planning, and urban functional services. The spatial distribution of urban land-cover types and their dynamic change data provide important data sources for effective urban management and planning and environmental research in the near future. 
Acknowledgments: Yunyun Feng acknowledges the financial support from the Zhejiang Agriculture and Forestry University's Research and Development Fund (2013FR052). This research was made possible by funds from FAPESP, Fundação de Amparo a Pesquisa do Estado de São Paulo (processo 2012/51465-0), under the São Paulo Excellence Chairs Program, awarded to Emilio F. Moran as PI. It was also made possible by Michigan State University through research funds provided to Dengsheng Lu and Emilio F. Moran. Luciano Vieira Dutra and Miquéias Freitas Calvi thank CNPq for supporting fieldwork through grants \#401528/2012-0, \#309135/2015-0, and \#409936 2013-8. Part of the imagery used in this research was provided by funds from INPE.

Author Contributions: Dengsheng Lu and Emilio F. Moran developed the analytical framework. Yunyun Feng did the image preparation, land-cover classification and change detection. Dengsheng Lu conducted the resultant analysis and wrote the initial manuscript. Luciano Dutra, Miquéias Freitas Calvi, and Maria Antonia Falcão de Oliveira designed the field data-collection plan and collected field survey data. All authors contributed to the editing/discussion of the manuscript.

Conflicts of Interest: The authors declare no conflicts of interest. The founding sponsors had no role in the design of the study; in the collection, analyses, or interpretation of data; in the writing of the manuscript; or in the decision to publish the results.

\section{References}

1. Fearnside, P.M. Dams in the Amazon: Belo Monte and Brazil's Hydroeletric Development of the Xingu River Basin. Environ. Manag. 2006, 38, 16-27. [CrossRef] [PubMed]

2. Santos, S.M.S.B.M.; Hernandez, F.M. (Eds.) Painel de Especialistas: Análise Crítica do Estudo de Impacto Ambiental do Aproveitamento Hidrelétrico de Belo Monte. Belém, Brazil. 2009. Available online: https: //www.internationalrivers.org/sites/default/files/attached-files/belo_monte_pareceres_ibama_online_3.pdf (accessed on 19 April 2017).

3. Rosenberg, D.M.; Berkes, F.; Bodaly, R.A.; Hecky, R.E.; Kelly, C.A.; Rudd, J.W.M. Large-scale impacts of hydroelectric development. Environ. Rev. 1997, 5, 27-54. [CrossRef]

4. Lu, D.; Weng, Q. A survey of image classification methods and techniques for improving classification performance. Int. J. Remote Sens. 2007, 28, 823-870. [CrossRef]

5. Lu, D.; Batistella, M.; Li, G.; Moran, E.; Hetrick, S.; Freitas, C.; Dutra, L.; Sant'Anna, S.J.S. Land use/cover classification in the Brazilian Amazon using satellite images. Braz. J. Agric. Res. 2012, 47, 1185-1208. [CrossRef] [PubMed]

6. Zhu, Z.; Woodcock, C.E. Continuous change detection and classification of land cover using all available Landsat data. Remote Sens. Environ. 2014, 144, 152-171. [CrossRef]

7. Asner, G.P. Cloud cover in Landsat observations of the Brazilian Amazon. Int. J. Remote Sens. 2001, 22, 3855-3862. [CrossRef]

8. Lu, D.; Hetrick, S.; Moran, E.; Li, G. Application of time series Landsat images to examining land use/cover dynamic change. Photogramm. Eng. Remote Sens. 2012, 78, 747-755. [CrossRef]

9. Lu, D.; Li, G.; Moran, E. Current situation and needs of change detection techniques. Int. J. Image Data Fusion 2014, 5, 13-38. [CrossRef]

10. Singh, A. Digital change detection techniques using remotely-sensed data. Int. J. Remote Sens. 1989, 10, 989-1003. [CrossRef]

11. Hansen, M.C.; Loveland, T.R. A review of large area monitoring of land cover change using Landsat data. Remote Sens. Environ. 2012, 122, 66-74. [CrossRef]

12. Lu, D.; Li, G.; Moran, E.; Batistella, M.; Freitas, C. Mapping impervious surfaces with the integrated use of Landsat Thematic Mapper and radar data: A case study in an urban-rural landscape in the Brazilian Amazon. ISPRS J. Photogramm. Remote Sens. 2011, 66, 798-808. [CrossRef]

13. Lu, D.; Moran, E.; Hetrick, S. Detection of impervious surface change with multitemporal Landsat images in an urban-rural frontier. ISPRS J. Photogramm. Remote Sens. 2011, 66, 298-306. [CrossRef] [PubMed]

14. Lu, D.; Hetrick, S.; Moran, E.; Li, G. Detection of urban expansion in an urban-rural landscape with multitemporal QuickBird images. J. Appl. Remote Sens. 2010, 4, 041880. [CrossRef] [PubMed]

15. Lu, D.; Hetrick, S.; Moran, E. Land cover classification in a complex urban-rural Landscape with QuickBird imagery. Photogramm. Eng. Remote Sens. 2010, 76, 1159-1168. [CrossRef]

16. Su, W.; Li, J.; Chen, Y.; Liu, Z.; Zhang, J.; Low, T.M.; Suppiah, I.; Hashim, S.A.M. Textural and local spatial statistics for the object-oriented classification of urban areas using high resolution imagery. Int. J. Remote Sens. 2008, 29, 3105-3117. [CrossRef] 
17. Reis, M.; Dutra, L.V.; Sant'anna, S.; Escada, M. Examining multi-legend change detection in Amazon with pixel and region based methods. Remote Sens. 2017, 9, 77. [CrossRef]

18. Dos Santos, J.A.; Gosselin, P.H.; Philipp-Foliguet, S.; Torres, R.D.S.; Falcao, A.X. Interactive multiscale classification of high-resolution remote sensing images. IEEE J. Sel. Top. Appl. Earth Obs. Remote Sens. 2013, 6, 2020-2034. [CrossRef]

19. Myint, S.W.; Gober, P.; Brazel, A.; Grossman-Clarke, S.; Weng, Q. Per-pixel vs. object-based classification of urban land cover extraction using high spatial resolution imagery. Remote Sens. Environ. 2011, 115, 1145-1161. [CrossRef]

20. Robertson, L.D.; King, D.J. Comparison of pixel- and object-based classification in land cover change mapping. Int. J. Remote Sens. 2011, 32, 1505-1529. [CrossRef]

21. Gao, Y.; Mas, J.F.; Maathuis, B.H.P.; Zhang, X.; Van Dijk, P.M. Comparison of pixel-based and object-oriented image classification approaches-A case study in a coal fire area, Wuda, Inner Mongolia, China. Int. J. Remote Sens. 2006, 27, 4039-4055. [CrossRef]

22. Huang, X.; Zhang, L. An SVM ensemble approach combining spectral, structural, and semantic features for the classification of high-resolution remotely sensed imagery. IEEE Trans. Geosci. Remote Sens. 2013, 51, 257-272. [CrossRef]

23. Demir, B.; Bruzzone, L. Histogram-based attribute profiles for classification of very high resolution remote sensing images. IEEE Trans. Geosci. Remote Sens. 2016, 54, 2096-2107. [CrossRef]

24. Qian, Y.; Zhou, W.; Yan, J.; Li, W.; Han, L. Comparing machine learning classifiers for object-based land cover classification using very high resolution imagery. Remote Sens. 2014, 7, 153-168. [CrossRef]

25. Coppin, P.; Jonckheere, I.; Nackaerts, K.; Muys, B.; Lambin, E. Digital change detection methods in ecosystem monitoring: A review. Int. J. Remote Sens. 2004, 25, 1565-1596. [CrossRef]

26. Hussain, M.; Chen, D.; Cheng, A.; Wei, H.; Stanley, D. Change detection from remotely sensed images: From pixel-based to object-based approaches. ISPRS J. Photogramm. Remote Sens. 2013, 80, 91-106. [CrossRef]

27. Lu, D.; Mausel, P.; Brondízio, E.; Moran, E. Change detection techniques. Int. J. Remote Sens. 2004, 25, 2365-2407. [CrossRef]

28. Chen, Y.; Lu, D.; Luo, G.; Huang, J. Detection of vegetation abundance change in the alpine tree line using multitemporal Landsat Thematic Mapper imagery. Int. J. Remote Sens. 2015, 36, 4683-4701. [CrossRef]

29. Huang, C.; Goward, S.N.; Masek, J.G.; Thomas, N.; Zhu, Z.; Vogelmann, J.E. An automated approach for reconstructing recent forest disturbance history using dense Landsat time series stacks. Remote Sens. Environ. 2010, 114, 183-198. [CrossRef]

30. Lu, D.; Li, G.; Moran, E.; Hetrick, S. Spatiotemporal analysis of land-use and land-cover change in the Brazilian Amazon. Int. J. Remote Sens. 2013, 34, 5953-5978. [CrossRef] [PubMed]

31. Calvi, M.F. Fatores de adoção de sistemas agroflorestais por agricultores familiares do município de Medicilândia, Pará. Núcleo de Ciências Agrárias e Desenvolvimento Rural. Dissertação de Mestrado, Universidade Federal do Pará, Belém, Brazil, 2009. (In Portuguese)

32. Moran, E.F. Developing the Amazon; Indiana University Press: Bloomington, IN, USA, 1981.

33. PMA. Estimativa da População Urbana de Altamira a Partir do Acesso aos Serviços Médico-Hospitalares; Prefeitura Municipal de Altamira: Altamira, Brazil, 2013.

34. Leturcq, G. Differences and similarities in impacts of hydroeletric dams between North and South of Brazil. Ambient. Soc. 2016, 19, 265-286. [CrossRef]

35. ELETROBRÁS. Estudo de Impacto Ambiental-EIA. Relatório de Impacto Ambiental da Usina Hidrelétrica de Belo Monte-RIMA Belo Monte; Eletrobrás: Rio de Janeiro, Brazil, 2009.

36. Chander, G.; Markham, B.L.; Helder, D.L. Summary of current radiometric calibration coefficients for Landsat MSS, TM, ETM+, and EO-1 ALI sensors. Remote Sens. Environ. 2009, 113, 893-903. [CrossRef]

37. Chavez, P.S., Jr. Image-based atmospheric corrections: Revisited and improved. Photogramm. Eng. Remote Sens. 1996, 62, 1025-1036.

38. Pohl, C.; van Genderen, J.L. Multisensor image fusion in remote sensing: Concepts, methods, and applications. Int. J. Remote Sens. 1998, 19, 823-854. [CrossRef]

39. Zhang, J. Multisource remote sensing data fusion: Status and trends. Int. J. Image Data Fusion 2010, 1, 5-24. [CrossRef]

40. Lu, D.; Li, G.; Moran, E.; Dutra, L.; Batistella, M. A comparison of multisensor integration methods for land-cover classification in the Brazilian Amazon. GISci. Remote Sens. 2011, 48, 345-370. [CrossRef] 
41. Liu, J.G. Smoothing Filter-based Intensity Modulation: A spectral preserve image fusion technique for improving spatial details. Int. J. Remote Sens. 2000, 21, 3461-3472. [CrossRef]

42. Karathanassi, V.; Kolokousis, P.; Ioannidou, S. A comparison study on fusion methods using evaluation indicators. Int. J. Remote Sens. 2007, 28, 2309-2341. [CrossRef]

43. Laben, C.A.; Brower, B.V. Process for Enhancing the Spatial Resolution of Multispectral Imagery Using Pan-Sharpening. U.S. Patent No. 6011875, 4 January 2000.

44. Haralick, R.M.; Shanmugam, K. Textural features for image classification. IEEE Trans. Syst. Man Cybern. 1973, 3, 610-621. [CrossRef]

45. Lu, D.; Li, G.; Moran, E.; Dutra, L.; Batistella, M. The roles of textural images in improving land-cover classification in the Brazilian Amazon. Int. J. Remote Sens. 2014, 35, 8188-8207. [CrossRef]

46. Laurin, G.V.; Liesenberg, V.; Chen, Q.; Guerriero, L.; Del Frate, F.; Bartolini, A.; Coomes, D.; Wilebore, B.; Lindsell, J.; Valentini, R. Optical and SAR sensor synergies for forest and land cover mapping in a tropical site in West Africa. Int. J. Appl. Earth Obs. Geoinf. 2013, 21, 7-16. [CrossRef]

47. Dey, V.; Zhang, Y.; Zhong, M.; Salehi, B. Image segmentation techniques for urban land cover segmentation of VHR imagery: Recent developments and future prospects. Int. J. Geoinf. 2013, 9, 15-35.

48. Zhang, L.; Jia, K.; Li, X.; Yuan, Q.; Zhao, X. Multi-scale segmentation approach for object-based land-cover classification using high-resolution imagery. Remote Sens. Lett. 2014, 5, 73-82. [CrossRef]

49. Li, W.; Saphores, J.D.M.; Gillespie, T.W. A comparison of the economic benefits of urban green spaces estimated with NDVI and with high-resolution land cover data. Landsc. Urban Plan. 2015, 133, 105-117. [CrossRef]

50. Odindi, J.O.; Mhangara, P. Green spaces trends in the city of Port Elizabeth from 1990 to 2000 using remote sensing. Int. J. Environ. Res. 2012, 6, 653-662.

51. McFeeters, S.K. The use of the Normalized Difference Water Index (NDWI) in the delineation of open water features. Int. J. Remote Sens. 1996, 17, 1425-1432. [CrossRef]

52. Thakkar, A.; Desai, V.; Patel, A.; Potdar, M. Land use/land cover classification using remote sensing data and derived indices in a heterogeneous landscape of a khan-kali watershed, Gujarat. Asian J. Geoinf. 2015, 14, 1-12.

53. Adam, E.; Mutanga, O.; Odindi, J.; Abdel-Rahman, E.M. Land-use/cover classification in a heterogeneous coastal landscape using RapidEye imagery: Evaluating the performance of random forest and support vector machines classifiers. Int. J. Remote Sens. 2014, 35, 3440-3458. [CrossRef]

54. Banerjee, B.; Bhattacharya, A.; Buddhiraju, K.M. A generic land-cover classification framework for polarimetric SAR images using the optimum Touzi decomposition parameter subset-An insight on mutual information-based feature selection techniques. IEEE J. Sel. Top. Appl. Earth Obs. Remote Sens. 2014, 7, 1167-1176. [CrossRef]

55. Congalton, R.G.; Green, K. Assessing the Accuracy of Remotely Sensed Data: Principles and Practices, 2nd ed.; CRC Press: Boca Raton, FL, USA, 2008.

56. Foody, G.M. Status of land cover classification accuracy assessment. Remote Sens. Environ. 2002, 80, $185-201$. [CrossRef]

57. Li, G.; Lu, D.; Moran, E.; Sant'Anna, S.J.S. A comparative analysis of classification algorithms and multiple sensor data for land use/land cover classification in the Brazilian Amazon. J. Appl. Remote Sens. 2012, 6. [CrossRef]

58. Angelis, C.F.; Freitas, C.D.C.; Valeriano, D.M.; Dutra, L.V. Multitemporal analysis of land use/land cover JERS-1 backscatter in the Brazilian Tropical Rainforest. Int. J. Remote Sens. 2002, 23, 1231-1240. [CrossRef]

59. Anjos, D.S.; Lu, D.; Dutra, L.V.; Sant'anna, S.J.S. Change detection techniques using multisensor data. In Remotely Sensed Data Characterization, Classification, and Accuracies; Thenkabail, P.S., Ed.; CRC Press: Boca Raton, FL, USA, 2016; pp. 377-397.

60. Lu, D.; Batistella, M.; Moran, E. Integration of Landsat TM and SPOT HRG images for vegetation change detection in the Brazilian Amazon. Photogramm. Eng. Remote Sens. 2008, 74, 421-430. [CrossRef]

61. Zhou, W.; Troy, A.; Grove, J.M. Object-based land cover classification and change analysis in the Baltimore metropolitan area using multi-temporal high resolution remote sensing data. Sensors 2008, 8, 1613-1636. [CrossRef] [PubMed]

62. Chen, G.; Hay, G.J.; Carvalho, L.M.T.; Wulder, M.A. Object-based change detection. Int. J. Remote Sens. 2012, 33, 4434-4457. [CrossRef] 
63. Zeng, Y.; Zhang, J.; van Genderen, J.L.; Zhang, Y. Image fusion for land cover change detection. Int. J. Image Data Fusion 2010, 1, 193-215. [CrossRef]

64. Chen, D.; Stow, D.A.; Gong, P. Examining the effect of spatial resolution and texture window size on classification accuracy: An urban environment case. Int. J. Remote Sens. 2004, 25, 2177-2192. [CrossRef]

(c) 2017 by the authors. Licensee MDPI, Basel, Switzerland. This article is an open access article distributed under the terms and conditions of the Creative Commons Attribution (CC BY) license (http:/ / creativecommons.org/licenses/by/4.0/). 